\title{
Unusual Localization of Darier-Ferrand Dermatofibrosarcoma: A Case Report
}

\author{
Abdelkoddous Bhihi ${ }^{*}$, Imane Yafi, Mehdi Sahibi, Oumkeltoum Elatiqui, Moulay Driss Elamrani, Yassine Benchamkha
}

Plastic Surgery Department, CHU Mohamed VI, Marrakech, Morocco

DOI: $10.36347 /$ sjmcr.2020.v08i02.003

| Received: 27.01.2020 | Accepted: 03.02.2020 | Published: 08.02.2020

*Corresponding author: Abdelkoddous Bhihi

Abstract

Case Report

Darier-Ferrand dermatofibrosarcoma is a fibrous tumour of the skin with high local malignancy, with progressive progression and high potential for recurrence. We report an unusual case of a 46-year-old patient with a distal extremity of the inner leg in which biopsy-exeresis histologically confirmed the nature of the tumour. We report this observation to illustrate the difficulty of surgical excision of this carcinoma in this particular anatomical region.

Keywords: Dermatofibrosarcoma-Localization-Distal extremity.

Copyright @ 2020: This is an open-access article distributed under the terms of the Creative Commons Attribution license which permits unrestricted use, distribution, and reproduction in any medium for non-commercial use (NonCommercial, or CC-BY-NC) provided the original author and source are credited.

\section{INTRODUCTION}

Darier and Ferrand dermatofibrosarcoma is a mesenchymal skin tumour of intermediate malignancy. It is a rare but not exceptional tumour, representing 0 . $1 \%$ of malignant skin tumours. We report the case of a Darier-Ferrand dermatofibrosarcoma of the distal end of the leg, highlighting the consequent diagnostic and therapeutic difficulties.

\section{Case Report}

The patient is 46 years old, with no particular pathological history, which has had an indurated nodular lesion on the inner side of the distal end of the leg for the past 2 years. In dermatology, he has had a partial biopsy, which histological study has shown that it is a Darier and Ferrand dermatofibrosarcoma. In view of the unusual location and doubt about the diagnosis, a biopsy-exeresis was performed confirming the initial diagnosis. The need for a large surgery with a healthy anatomical barrier that is unfortunately absent in this anatomical area led the treating team to discuss an amputation for optimal tumor control, which was refused by the patient who was lost to follow-up.

\section{DiscuSSION}

Darier-Ferrand dermatofibrosarcoma is a mesenchymal dermal tumour of intermediate malignancy first described in 1890 by Taylor [1]. This tumour can occur at any age with mean ages at diagnosis ranging from 28 to 47 years [2]. Our case of dermatofibrosarcoma is unusual because of its clinical appearance and location. According to the data in the literature, there is a predilection for the trunk, which is reached in 50 to $60 \%$ of cases. Members represent 20$30 \%$ of the locations and $15-20 \%$ is attributed to the head and neck $[3,4]$.

Mandalenakis and Venne [5] and Soulie $\delta$ al [6] found a preferential location on the anterior aspect of the trunk and proximal extremities. Publications concerning distal extremities are rare [7]. Surgery is the only therapeutic method that has been shown to be effective in eradicating the tumour and preventing recurrence [8]. The excision must comply with certain precise rules: monobloc excision with wide safety margins of 3 to $5 \mathrm{~cm}$ of healthy tissue, carrying a healthy barrier in depth. Indeed, non-Monobloc removals risk seeding the operating site. The absence of an anatomical barrier as well as the absence of Mohs technique at our center led us to ask for the indication of amputation for a better control of the tumor.

\section{CONCLUSION}

Darier-Ferrand's tumour is characterized by its slow progression, diagnostic difficulty, tendency towards recurrence, degeneration into fibrosarcoma possible after several recurrences. Our observation illustrates the possibility of localization at the distal end of the leg of this rare tumor and the need to evoke the diagnosis early and to perform surgical exeresis because the whole prognosis depends on it. 


\section{REFERENCES}

1. Taylor RW. Sarcomatous Tumors ressembling in some respects Kelo ïd. J Cutan Genitourin Dis. 1890; 8:384-387.

2. Traoré SS, Zida M, Baro FT, Boukoungou G, Goumbri OM, Sano D, Guira A. Le dermatofibrosarcome de Darier et Ferrand (DFDF). À propos de 7 CAS au CHU de Ouagadougou, Burkina Faso. Bull Soc Pathol Exot. 2007; 100(2):105-106.

3. Bendix-Hansen K, Myhre-Jensen O, Kaae S. Dermatofibrosarcoma protuberans: a clinicopathological study of nineteen cases and review of the world literature. Scand $\mathbf{J}$ Plast Reconstr Surg. 1983; 17(3):247-252.

4. Burkhardt BR, Soule EH, Winkelmann RK, Ivins JC. Dermatofibrosarcoma protuberans: study of fifty-six cases. Am J Surg. 1996; 111(5):638-644.
5. Mandalenakis N, Venne L. Dermatofibrosarcome protubérant évoluant depuis 25 ans avec 27 récidives. Ann Anapath. 1980; 25:139-50.

6. Soulie A, Georgeac C, Arnaud JP. Le dermatofibrome protubérant, une tumeur cutanée inhabituelle. J Chirur. 1994; 131:322-3.

7. Smola MG, Scharnagl E, Pierer G, Hellbom B. Dermatofibrosarcoma protuberans of the foot' surgical treatment with defect covering by radial forearm flap. Report of a case with review of the literature. Eur J Plast Surg. 1991;14(2):99-101.

8. Gattoni M, Tiberio R, Angeli L, Bornacina G, Boggio P, Annali G. Dermatofibrosarcoma protuberans: surgical treatment using the Tübingen technique (31 cases). Ann Dermatol Venereol. 2007; 134:31-4 